\title{
Spatial distribution of bivalve mollusc assemblages in the upwelling ecosystem of the continental shelf of Cabo Frio, Rio de Janeiro, Brazil
}

\author{
Abilio Soares-Gomes ${ }^{1} \&$ Flavio da Costa Fernandes ${ }^{2}$ \\ ${ }^{1}$ Departamento de Biologia Marinha, Universidade Federal Fluminense. Caixa Postal 100.644, 24001-970 Niterói, Rio de \\ Janeiro, Brasil. \\ 2 Instituto de Estudos do Mar Almirante Paulo Moreira. Rua Kioto 253, Praia dos Anjos, 28930-000 Arraial do Cabo, Rio de \\ Janeiro, Brasil.
}

\begin{abstract}
Bivalve mollusks of the continental shelf of Cabo Frio upwelling ecosystem were sampled monthly from February 1986 to February 1987 along a 30 to $60 \mathrm{~m}$ depth gradient. Mactra petiti Orbigny, 1846, and Tellina gibber Ihering, 1907 were constant species in 30 m; Nucula puelcha Orbigny, 1846, Adrana patagonica Orbigny, 1846, T. petitiana, T. gibber, and Corbula patagonica Orbigny, 1846 in $45 \mathrm{~m}$; and N. puelcha, T. gibber, C. patagonica, and C. caribaea in $60 \mathrm{~m}$. The number of rare species was similar along the depth gradient, ranging from six to ten species. The number of common species was higher in $60 \mathrm{~m}$ than in $30 \mathrm{~m}$. Some species showed a continuous distribution but changed the frequency and abundance along the bathymetric gradient. The mean density was higher in 45$60 \mathrm{~m}$ than in $30 \mathrm{~m}$, ranging from 15.6 ind. $\mathrm{m}^{-2}$, in $30 \mathrm{~m}$, to 68.1 ind. $\mathrm{m}^{-2}$, in $60 \mathrm{~m}$. There was no seasonal change in density nor in the taxocene structure during the studied period. On the other hand, the bivalve assemblage was spatially structured along the depth gradient, showing consistent changes from 30 to $60 \mathrm{~m}$ depths. Diversity and richness also follow this distribution pattern.
\end{abstract}

KEY WORDS. Benthic associations, community ecology, macrobenthos, soft-bottom, sublittoral.

RESUMO. Distribuição espacial das associações de moluscos bivalves na plataforma continental do ecossistema da ressurgência de Cabo Frio, Rio de Janeiro, Brasil. Os moluscos bivalves da plataforma continental do ecossistema da ressurgência do Cabo Frio foram amostrados mensalmente de fevereiro de 1986 a fevereiro de 1987, entre 30 a $60 \mathrm{~m}$ de profundidade. Mactra petiti e Tellina gibber Ihering, 1907 foram espécies constantes a 30 m; Nucula puelcha Orbigny, 1846, Adrana patagonica Orbigny, 1846, T. petitiana, T. gibber e Corbula patagonica Orbigny, 1846 a $45 \mathrm{~m}$; e $N$. puelcha, T. gibber, C. patagonica e C. caribaea a $60 \mathrm{~m}$. O número de espécies raras foi similar nas diferentes profundidades, variando entre seis a dez espécies. $O$ número de espécies comuns foi maior a $60 \mathrm{~m}$ que a $30 \mathrm{~m}$. Algumas espécies apresentaram distribuição contínua porém, com variação na freqüência e abundância ao longo do gradiente batimétrico. A densidde média foi maior a $45-60 \mathrm{~m}$ do que a $30 \mathrm{~m}$., variando entre 15,6 ind. $\mathrm{m}^{-2}(30 \mathrm{~m})$ a 68,1 ind. $\mathrm{m}^{-2}(60 \mathrm{~m})$. Não foram observadas mudanças sazonais na densidade ou na estrutura da associação de bivalves durante o período estudado. Por outro lado, a taxocenose mostrou-se estruturada ao longo do gradiente batimétrico, mostrando mudanças consistentes de 30 para $60 \mathrm{~m}$ de profundidade.

PALAVRAS CHAVE. Associações bentônicas, ecologia de comunidades, macrobentos, sublitoral, sedimentos não-consolidados.

Cabo Frio is situated on the coast of Rio de Janeiro State, central southeastern Brazil $\left(23^{\circ} \mathrm{S}, 42^{\circ} \mathrm{W}\right)$. In this portion of the Brazilian coast three water masses are present: the coastal water, the tropical water of the Brazil Current, and the South Atlantic Central Water (SACW). The main oceanographic feature of the region is the SACW upwelling, driven by local topography and north-northeast wind (EMILSON 1961).

According to VALENTIN (2001), the SACW up flow follows two stages: the first begins in mid-August/September (late aus- tral winter), and the second mainly from September to March (austral spring-summer). The increment of biomass (0,5-6,0 mg chlorophyll $\left.\mathrm{L}^{-1}\right)$ and primary production (2-14 $\left.\mathrm{mgC} \mathrm{m}^{-3} \mathrm{~h}^{-1}\right)$ due to upwelling event is low, comparing to similar systems elsewhere. In spite of this, local pelagic species composition and trophic structure change, and important fisheries species are supported by upwelling, such as sardines and squids, which use the area as recruitment and feeding grounds (Costa \& Fernandes 1993, Matsuura 1996). In situations of strong up- 
welling, SACW advances beyond the continental slope and invades the shelf to depths of about 50-80 m. This flow of SACW over the inner shelf influences the composition and abundance of benthic and demersal fishes, bringing species typical of deepsea habitats (NetTo \& Gaelzer 1991).

The effect of upwelling on benthic communities could be either positive or negative. In some circumstances, a heavy sedimentation of organic matter could induce hypoxic or anoxic conditions, leading to a benthic community with low diversity and high dominance of only a few species (ROWE 1985, TARAZONA \& ARNTZ 2001). The ecology of benthic invertebrates of the Cabo Frio upwelling system is poorly studied, similar to other Brazilian continental margin benthic habitats. A multidisciplinary oceanographic project carried out by the Admiral Paulo Moreira Sea Studies Institute generated some results about the local benthic invertebrates, but only data on echinoderms and anomuran crustaceans were published until now (VeNTURA \& Fernandes 1995, Ventura et al. 1997, da Gama \& Fernandes 1994). This work describes the distribution of the bivalve mollusc assemblages on the inner shelf and aims to contribute to the knowledge of the local ecosystem, as these invertebrates could represent an important link in the food chain from primary producers, such as phytoplancton and microphytobenthos, to predators, such as fishes (KAMERMANs 1992).

\section{MATERIAL AND METHODS}

Quantitative sediments samples were collected monthly from 30, 45, and 60 metres depths, from February 1986 to February 1987 , using a $0,1 \mathrm{~m}^{2}$ van Veen grab and a rectangular dredge. Two stations were sampled at each depth: 1-4 $(30 \mathrm{~m})$; 2-5 (45 m); 3-6 (60 m). Additionally, qualitative samples were taken by an otter-trawl net in order to improve the local species list, which was also improved with species that occurred as empty shells only and by species that occurred in stomach content of starfishes. A van Veen and a dredge sample unit were taken monthly in each station, and a single otter-trawl haul was done between stations located in the same depth isolines. Figure 1 shows the geographical situations of the study area and the sampling design adopted.

The macrozoobenthos was stained with rose Bengal, sieved out with $0.5 \mathrm{~mm}$ mesh size, and sorted under a stereomicroscope to determine the abundance of bivalve molluscs.

Data of density of each station were pooled according to austral seasons. Then, the mean density of each station were calculated and organized in a data matrix to calculate the BrayCurtis similarity. The resultant Bray-Curtis similarity matrix was used to run the one-way analysis of similarity (ANOSIM) permutation test (Clarke \& Green 1988). In this case, the ANOSIM test the null hypothesis that there is no seasonal difference in the bivalve taxocene structure.

The data of van Veen and grab were pooled and mean for each station, according to the bathymetric gradient. These data were used to determine the frequency of occurrence (F)

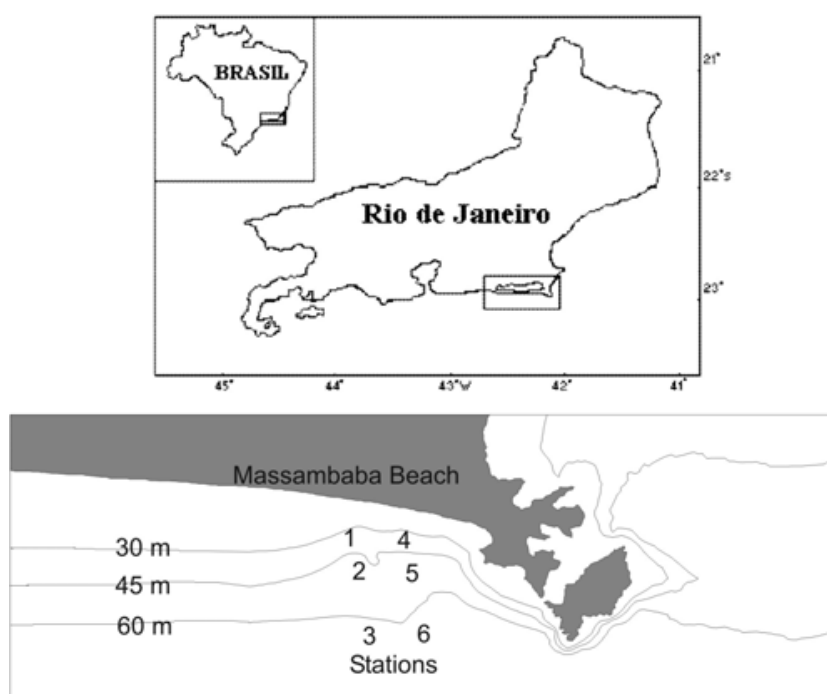

Figure 1. Geographical situation of the study area and the sampling stations.

proposed by GuILLE (1970), and depending to the value species were classified as constant ( $\mathrm{F}>50 \%)$, common $(10 \% \leq \mathrm{F} \leq$ $50 \%)$, and rare $(\mathrm{F}<10 \%)$.

The mean values calculated according to the bathymetric gradient were used to analyse the spatial distribution of the bivalve taxocene. In this case, only quantitative data of van Veen were employed. Both a cluster (UPGMA method) and an ordination technique (NMDS) were performed to fourth root transformed data, using Bray-Curtis similarity, as an exploratory data analysis. The null hypothesis that there is no difference in the bivalve taxocene structure along the 30 to $60 \mathrm{~m}-$ depth gradient was tested by ANOSIM.

The Shannon diversity $\left(\log _{2}\right)$ and Pielou evenness indexes were calculated for each station, and the null hypothesis that there is no difference in density, diversity, evenness and richness (number of species) along the depth gradient was tested by ANOVA. Prior to the analysis the data were normalised by $\log$ transformation.

Besides species collected by otter trawl net, species that are not typical soft-bottom dwellers, species with frequency of occurrence below $5 \%$ were also not considered in data analysis.

Several abiotic parameters of the sediment were measured for later try to explain the biological distribution. Granulometric fractions of the sediments (coarse sand, median sand, fine sand and silt-clay) were determined by standard dry-sieve and pipette method (Suguio 1973), and mean grain size and sorting coefficient were calculated according to FoLK \& W WRD (1957). Organic carbon, nitrogen and phosphorus were determined by titration methods, following FAO (1975) methodology. The biodetritic carbonate content $\left(\mathrm{CaCO}_{3}\right)$ was obtained by $\mathrm{HCl} 10 \%$ attack. An exploratory data analysis was performed 
(Principal Component Analysis-PCA) to the log transformed normalised mean data of the abiotic variables. Data in percentages were transformed to arcosine instead of log.

Taxonomic identification was based shell features following Aвbott (1974), Rios (1994), and Merlano \& Hegedus (1994), among others.

\section{RESULTS}

The sampling devices employed collected a total of 44 species, belonging to 38 genera and 27 families (see Tab. I).

Tablell show the frequency of occurrence and total abundance of the species collected by grab and dredge samples in different depths. Mactra petiti Orbigny, 1846 (Mactridae), and Tellina gibber Ihering, 1907 (Tellinidae) were constant species in $30 \mathrm{~m}$; Nucula puelcha Orbigny, 1846 (Nuculidae), Adrana patagonica Orbigny, 1846 (Nuculanidae), Tellina petitiana Orbigny, 1846 (Tellinidae), Tellina gibber Ihering, 1907 (Tellinidae), and Corbula patagonica Orbigny, 1846 (Corbulidae) in 45 $\mathrm{m}$; and Nucula puelcha Orbigny, 1846 (Nuculidae), Tellina gibber Ihering, 1907 (Tellinidae), Corbula patagonica Orbigny, 1846 (Corbulidae), and Corbula caribaea Orbigny, 1846 (Corbulidae) in $60 \mathrm{~m}$. The number of rare species was similar al ong the depth gradient, ranging from six to ten species. The number of com- mon species increased from $30 \mathrm{~m}$ (6 species) to $60 \mathrm{~m}$ (14 species). Some species showed a continuous distribution but changed in frequency and abundance along the bathymetric gradient. The frequency of $\mathrm{N}$. puelcha, e.g., increased about three fold and its abundance more than 10 folds from 30 to $45-60$ $\mathrm{m}$. Both total species number and total abundance were higher in 45 and $60 \mathrm{~m}$ depths than in $30 \mathrm{~m}$ depth.

The mean density, determined for grab samples was higher, during the studied period, in 45 and $60 \mathrm{~m}$ than in 30 $\mathrm{m}$, ranging from 15,6 ind. $\mathrm{m}^{-2}$, in $30 \mathrm{~m}$, to 68,1 ind. $\mathrm{m}^{-2}$, in $60 \mathrm{~m}$ (Fig. 2). Tellina gibber was the dominant species in $30 \mathrm{~m}(41,49$ and $53,85 \%$, in stations 1 and 4, respectively). In $45 \mathrm{~m} \mathrm{~N}$. puelcha was dominant in station $2(55,47 \%)$, and T. gibber in station 4 (34,96\%). The abundance distribution in $60 \mathrm{~m}$ was more homogeneous, with the maximum dominance of $37,15 \%$ in station 6 by $N$. puelcha. There was no significant difference in the density among seasons.

According to ANOSIM test, there is no seasonal change in the taxocene structure during the studied period (Global $R$ $=-0,025 ; p=55.6 \%)$. On the other hand, the cluster analysis and NMDS ordination clearly show that the taxocene was spatially structured al ong the depth gradient. Stations in $45 \mathrm{~m}$ are more closely related to $60 \mathrm{~m}$ stations, both in the dendrogram

Table I. List of species collected by grab, dredge, or otter-trawl. (*) Empty shells only, (**) found in the gut content of Astropecten brasiliensis.

\begin{tabular}{|c|c|}
\hline Species & Species (cont.) \\
\hline Abra lioica (Dall, 1881) & Macoma cleryana (Orbigny, 1846) \\
\hline Adrana patagonica (orbigny, 1846) & Macoma tenta (Say, 1834) \\
\hline Anadara chmnitzi (Philippi, 1851) & M actra janeiroensis E.A. Smith, 1915 \\
\hline Anadara ovalis (Bruguière, 1789) & Mactra petiti Orbigny, 1846 \\
\hline Cardiomya perrostrata (Dall, 1881) & Malletia cumingii (Hanley, 1860) \\
\hline Carditamera plata (Ihering, 1907) & Martesia fragilis Verrill \& Bush, 1890 \\
\hline Chione pubera (Bory Saint-Vincent, 1827) & M usculus lateralis (Say, 1822) \\
\hline Chlamys tehuelchus (Orbigny, 1846) & Myrtea lens (Verrill \& Smith, 1880)* \\
\hline Codakia pectinella C.B. Adams, 1852 & Nucula puelcha Orbigny, 1846 \\
\hline Cooperella atlantica Rehder, 1943 & Nuculana larranagai Klappenbach \& Scarabino, 1968 \\
\hline Corbula caribaea Orbigny, 1842 & Periploma compressa Orbigny, 1846 \\
\hline Corbula lyoni Pilsbry, 1897 & Perna perna (Linnaeus, 1758) \\
\hline Corbula patagonica Orbigny, 1846 & Pitar rostratus (Koch, 1844) \\
\hline Crassinella lunulata (Conrad, 1834) & Poromya cymata Dall, $1889 *$ \\
\hline Crassostrea rizophorae (Guilding, 1828) & Raeta plicatella (Lamarck, 1818) ** \\
\hline Crenella divaricata (Orbigny, 1846) & Semele nuculoides (Conrad, 1841) \\
\hline Cuspidaria braziliensis E.A. Smith, 1915 * & Solemya patagonica E. A. Smith, 1885 \\
\hline Entodesma beana (Orbigny, 1842) & Tellina gibber Ihering, 1907 \\
\hline Ervilia concentrica (Holmes, 1860) & Tellina petitiana Orbigny, 1846 \\
\hline Glycymeris longior (Sowerby, 1833) & Thyasira croulinensis Jeffreys, 1874 \\
\hline Limaria thryptica (Penna, 1971) & Trachycardium muricatum (Linnaeus, 1758) \\
\hline Limopsis antillensis Dall, 1881 & Transenpitar americana (Doello-Jurado, 1951) \\
\hline
\end{tabular}


Table II. Frequency of occurrence (F) and total abundance (A) - the sum of individuals during the whole sampling time - of species collected by grab and dredge on different depths.

\begin{tabular}{|c|c|c|c|c|c|c|}
\hline \multirow{3}{*}{ Species } & \multicolumn{6}{|c|}{ Depth } \\
\hline & \multicolumn{2}{|c|}{$30 \mathrm{~m}$} & \multicolumn{2}{|c|}{$45 \mathrm{~m}$} & \multicolumn{2}{|c|}{$60 \mathrm{~m}$} \\
\hline & $F(\%)$ & (A) & $F(\%)$ & (A) & $F(\%)$ & (A) \\
\hline N. puelcha & 33.3 & 12 & 83.3 & 108 & 83.3 & 149 \\
\hline M. cumingii & 5.5 & 2 & 38.9 & 13 & 44.4 & 36 \\
\hline A. patagonica & 5.5 & 2 & 55.5 & 44 & 44.4 & 22 \\
\hline N. larranagai & 0 & 0 & 0 & 0 & 22.2 & 7 \\
\hline S. patagonica & 0 & 0 & 11.1 & 2 & 27.8 & 9 \\
\hline A. chemnitz & 0 & 0 & 16.7 & 4 & 0 & 0 \\
\hline L. ovalis & 11.1 & 11 & 22.2 & 39 & 5.5 & 2 \\
\hline G. longior & 16.7 & 3 & 0 & 0 & 0 & 0 \\
\hline L. antillensis & 5.5 & 1 & 0 & 0 & 0 & 0 \\
\hline C. divaricata & 0 & 0 & 22.2 & 6 & 0 & 0 \\
\hline C. tehuelchus & 5.5 & 8 & 33.3 & 39 & 5.5 & 1 \\
\hline L. thryptica & 0 & 0 & 5.5 & 1 & 38.9 & 8 \\
\hline C. pectinella & 0 & 0 & 27.8 & 5 & 0 & 0 \\
\hline T. croulinensis & 5.5 & 1 & 0 & 0 & 44.4 & 8 \\
\hline C. lunulata & 50.0 & 19 & 22.2 & 6 & 5.5 & 1 \\
\hline C. plata & 0 & 0 & 0 & 0 & 5.5 & 1 \\
\hline T. muricatum & 0 & 0 & 0 & 0 & 5.5 & 1 \\
\hline M. petiti & 55.5 & 19 & 5.5 & 1 & 5.5 & 1 \\
\hline M. janeiroensis & 0 & 0 & 5.5 & 1 & 16.7 & 3 \\
\hline E. concentrica & 5.5 & 1 & 0 & 0 & 0 & 0 \\
\hline T. petitiana & 50.0 & 19 & 66.7 & 90 & 0 & 0 \\
\hline T. gibber & 61.1 & 56 & 72.2 & 115 & 55.5 & 62 \\
\hline M. tenta & 0 & 0 & 0 & 0 & 16.7 & 4 \\
\hline S. nuculoides & 0 & 0 & 5.5 & 1 & 0 & 0 \\
\hline A. lioica & 0 & 0 & 11.1 & 41 & 22.2 & 9 \\
\hline C. pubera & 5.5 & 2 & 0 & 0 & 0 & 0 \\
\hline T. americana & 16.7 & 4 & 38.9 & 14 & 0 & 0 \\
\hline P. rostratus & 5.5 & 1 & 50.0 & 16 & 2.2 & 5 \\
\hline C. atlantica & 0 & 0 & 0 & 0 & 11.1 & 3 \\
\hline C. Iyoni & 5.5 & 1 & 5.5 & 2 & 33.3 & 7 \\
\hline C. patagonica & 5.5 & 3 & 61.1 & 101 & 88.9 & 116 \\
\hline C. caribaea & 0 & 0 & 27.8 & 10 & 55.5 & 23 \\
\hline P. compressa & 0 & 0 & 0 & 0 & 27.8 & 6 \\
\hline E. beana & 0 & 0 & 0 & 0 & 5.5 & 2 \\
\hline C. perrostrata & 0 & 0 & 5.5 & 1 & 11.1 & 4 \\
\hline Total Abundance & & 165 & & 660 & & 491 \\
\hline Total of species & 18 & & 23 & & 25 & \\
\hline
\end{tabular}

and in the space ordination dimensions (Fig. 3). The null hypothesis about spatial distribution, tested by ANOSIM, was rejected, indicating that the bivalve taxocene is highly structured along the depth gradient (Tab. III). The Shannon diver- sity and richness were statistically different along the depth gradient, and were higher in 45 and $60 \mathrm{~m}$ than 30m (Figs 4 and 5). On the other hand, the evenness was statistically higher in $30 \mathrm{~m}$ than in 45 and $60 \mathrm{~m}$ (Fig. 6). 
Table II. Results of ANOSIM for the null hypothesis about the spatial distribution along the depth gradient.

\begin{tabular}{cccc}
\hline Global R & $\begin{array}{c}\text { Significance level of } \\
\text { sample statistic (\%) }\end{array}$ & Number of permutations & $\begin{array}{c}\text { Number of permuted statistics } \\
\text { greater than or equal to global R }\end{array}$ \\
\hline 0.44 & 0.1 & 999 & 0 \\
Groups & R Statistic & Significance Level (\%) & 0 \\
$30-45 \mathrm{~m}$ & 0.404 & 0.1 & 0 \\
$30-60 \mathrm{~m}$ & 0.665 & 0.1 & 0 \\
$45-60 \mathrm{~m}$ & 0.284 & 0.1 & 0 \\
\hline
\end{tabular}

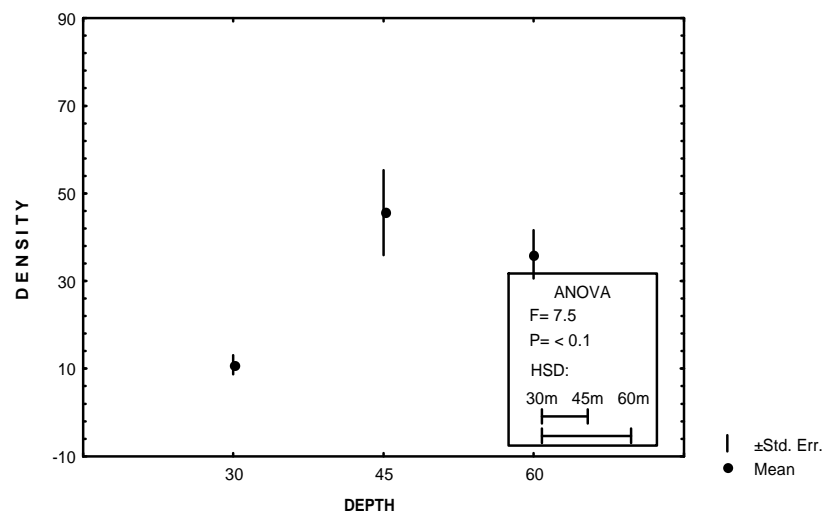

Figure 2. Plot of mean and standard error values of density on the depth gradient. The results of ANOVA and Tukey Honest Significant Difference (HSD) are shown inside the small box.

Table IV shows the means of the abiotic variables in each station. The organic content of sediment (OP, ON) was higher in 45 and $60 \mathrm{~m}$ stations than in $30 \mathrm{~m}$, as well as the biodetritic carbonate concentration. The median sand fraction was higher at 30-45 $\mathrm{m}$ stations, while the fine sand fraction was higher at $60 \mathrm{~m}$ stations. This shift in the predominance of the grain size fraction along the depth gradient is in part reflected by the mean grain size values. The sorting of sedimentary grains was higher in $30 \mathrm{~m}$ stations (note that the smaller the phi value, the higher the grain size!). The exploratory data analysis performed on the mean values of abiotic variables showed that the first 2 PCA axes account for $88 \%$ of the abiotic data variance. The $60 \mathrm{~m}$ stations ( 3 and 6) show a clear spatial disjunction in relation to 30-45 m stations (with exception of station 5) along the axis 1 of the PCA ordination that represent the hydrodynamic gradient (Fig. 7).

\section{DISCUSSION}

Upwelling can be a continuous or a pulse phenomenon throughout the year (Rowe 1985, TARAZONA \& ARNTZ 2001). In case of occurring in pulse, it is plausible to hypothesize that benthic structure community changes as a result of the dynamic of organic matter input. LEVINTON (1972) speculated that temporal variation in abundance of suspension-feeding bivalves is caused by seasonal variability in the phytoplanctonic food source,

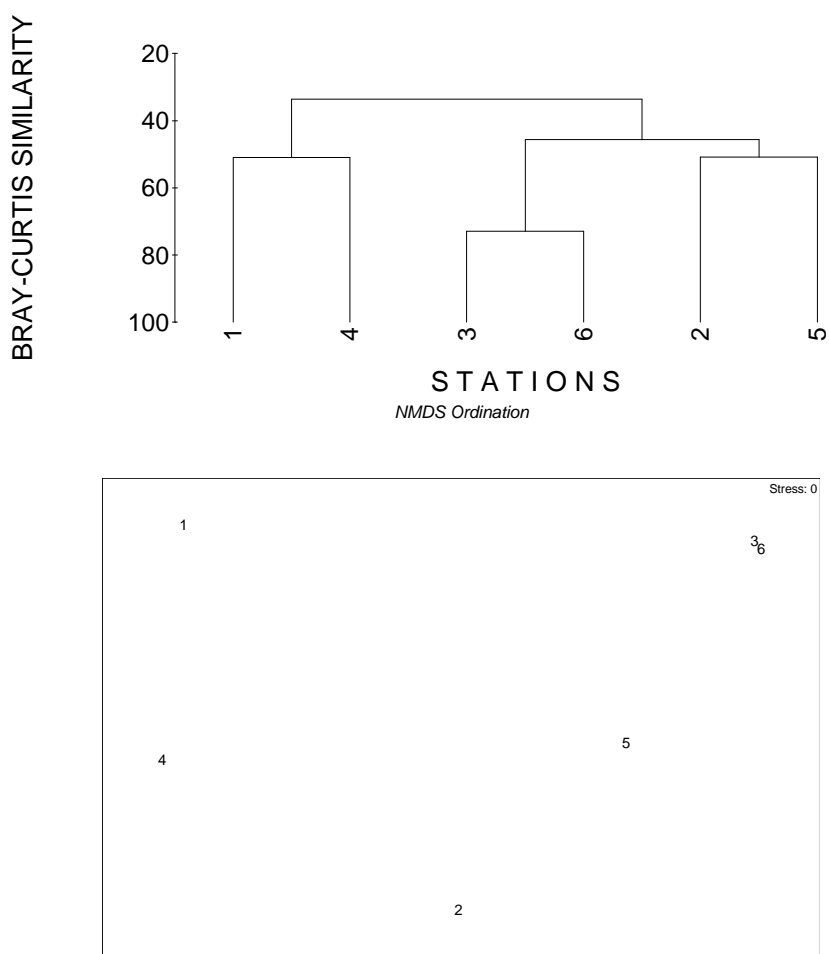

Figure 3. Dendrogram and NMDS ordination plot of van Veen abundance data.

and that these animals have evolved means of rapidly increasing their numbers in response to periods of food abundance. In periods of upwelling, the higher input of organic matter from the pelagic system could improve the benthos if this input does not lead to anoxic conditions. The Cabo Frio upwelling is a pulse event, occurring at any time of the year, although more commonly during spring and summer periods (VALENTIN 2001). During the studied period thestructure of the benthos in the region did not change in time, revealing that the increment of phytoplankton biomass was not enough to shift the patterns of species dominance nor bivalve density. It could be speculated that the extra organic matter driven by upwelling was being consumed by pelagic species in the water column itself with very littlebeing transported to the seafloor. Another possibility would 

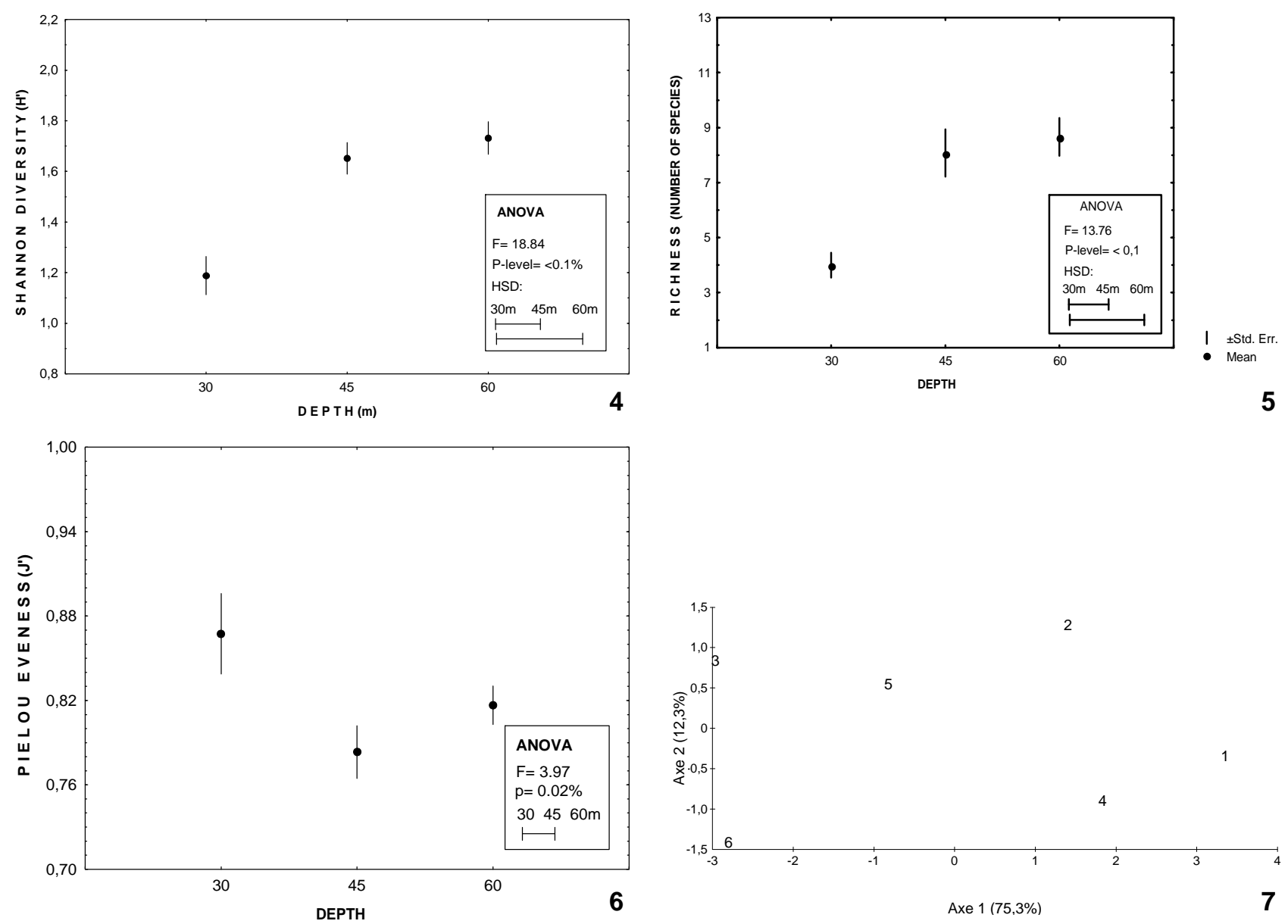

Figures 4-7. (4-6) Plot of mean and standard error values of: (4) Shannon diversity index on the depth gradient; (5) number of species (richness) on the depth gradient; (6) Pielou evenness index on the depth gradient. The results of ANOVA and Tukey Honest Significant Difference (HSD) are show inside the small box; (7) PCA ordination plot of stations based on abiotic variables.

be that the population dynamic of none of the bivalve species occurring in the area fit to the increment in food availability.

Not only temporal food availability promotes changes in biotic structure. Assemblages of more mobile species could show a faster shift in their composition in response to changes in environmental temperature. This seems to bethecase for local benthic and demersal deep-sea fishes reported by NetTo \& Gaelzer (1991), such as the red porgy Pagrus pagrus (Linnaeus, 1758), the cusk-eel Genypterus brasiliensis (Regan, 1903), the silver hake Merluccius hubbsi Marine, 1933, and the anglerfish Lophius gastrophysus Miranda Ribeiro, 1915, that follow the intrusion of SACW over the shelf. This behaviour was also described for the crab Portunus spinicarpus and the snail Zidona dufresnei (Donovan, 1823), by PIRES-VAnin et al. (1995) for the coast of Ubatuba, southern of Cabo Frio. Benthic sedentary and sessile species, such as bivalve mollusks, however, are not expected to exhibit this behavior. In this case, the taxocene is more structured in time if not affected by another environmental variable or by intrinsic factors.

In relation to the spatial distribution, the bivalvetaxocene is clearly structured along the depth gradient studied. Both the exploratory data analysis (cluster and NMDS ordination) and hypothesis testing (ANOSIM) results showed a consistent shift in the taxocene structure between 30 and $60 \mathrm{~m}$ stations. The 45 $\mathrm{m}$ stations seem to be a transition zone between 30 and $60 \mathrm{~m}$ isobaths. This same spatial pattern was found for echinoderms by Ventura \& FeRnANDEs (1995) and for benthic and demersal fishes by NetTo \& Gaelzer (1991). Such a clear spatial pattern in a narrow depth gradient is amazing since, as Franz (1976) stated, "the structure of benthic communities varies in conjunction with gradual changes along environmental gradients. The resulting continuum of species distribution implies the absence of precise boundaries separating such communities, except at points where the environmental gradients steepened to form natural or habitat separation". Although there is a set of species that shift their

Revista Brasileira de Zoologia 22 (1): 73-80, março 2005 
frequency and density along the gradient, the majority of species showed a continuum distribution. Only four and seven species were found exclusively on 30 and $60 \mathrm{~m}$ isolines, respectively. When 45 and $60 \mathrm{~m}$ isolines are analysed together, the list increases to 13 exclusive species. On $45 \mathrm{~m}$ isoline there were found only four exclusive species. This fact reinforces the idea that the $45 \mathrm{~m}$ isoline is an ecotone zone. These results are in accordance with the concepts of communities that recognize this apparent ambiguity between continuum and discrete entities. "Communities have a spatially open structure, in which the species that coexist in a given locality may extend more or less independently into other communities" (SCHLUTER \& RiCKLefs 1993).

Along the Brazilian coast, spatial distribution of bivalve assemblages related to sediment types was also found by GONÇALVES \& LANA (1991), on a section of the Southeast Brazilian continental shelf, by ABSALÃo (1991), on the continental shelf off Lagoa dos Patos (Rio Grande do Sul) estuary, and by GriLlo et al. (1998), in a sheltered habitat of Ilha Grande (Rio de Janeiro) with tidal current influence. The bivalve assemblages seem to have a recurrent spatial distribution pattern on the Brazilian south-eastern shelf, at least on mid-shelf ( > $50 \mathrm{~m}$ depth), on bottoms where fine grain fractions are greater. According to GonçaLves \& Lana (1991) recurrent assemblages dominated by Corbula caribaea Orbigny, 1846, Macoma tenta (Say, 1834) (Tellinidae), and Limaria thryptica (Penna, 1971) (Limidae) occur on these bottoms. These species also occur at Cabo Frio, but only Corbula caribaea could be considered typical of these bottoms.

The granulometric features in the area suggest a hydrodynamic gradient that could be conditioning the spatial distribution of the bivalve taxocene. Greater contents of organic matter and fine grains indicate that action of waves or bottom currents are less effective in $60 \mathrm{~m}$ depth stations. The higher values of grain sorting in shallower stations also corroborate this thought, since well-sorted sediments are typical of high-energy environments whereas more heterogeneous ones occur in low-energy areas (GRAY 1981). Specific diversity has been correlated with habitat heterogeneity among other environmental variables. Fine sediments with high silt-clay contents are well sorted and structurally homogeneous. These sediments have few potential niches and are characteristically poor in species number comparing to poorly-sorted sediments that show more structural heterogeneity (Gray 1981). In Cabo Frio, the Shannon diversity was higher in deeper stations than in shallow ones. These higher values of diversity in deeper stations were due to the higher number of species (richness) rather than due to the evenness component of diversity, indicating a possible positive correlation between diversity and habitat heterogeneity.

\section{CONCLUSIONS}

The abundance and occurrence of bivalves mollusks seems to have no links with upwelling phenomena at Cabo Frio region as there was no seasonal change in density nor in the assemblage structure during the period studied. On the other hand,

Revista Brasileira de Zoologia 22 (1): 73-80, março 2005 
the assemblage is spatially structured al ong the depth gradient, showing a consistent shift between 30 and $60 \mathrm{~m}$ isobaths, with the $45 \mathrm{~m}$ isobaths representing a transition zone. The increasing in the richness and diversity found in $60 \mathrm{~m}$ isobaths could be attributed to a higher spatial heterogeneity in this depth.

\section{ACKOWLEDGES}

The authors are in debt with Dra. Lúcia Maria Zani Richinitti and an anonymous referee for valuables suggestions and comments that improve the article.

\section{REFERENCES}

Аввот, R.T. 1974. American seashells. New York, van Nostrand Reinhold, 663p.

ABSALÃo, R.S. 1991. Environmental discrimination among softbottom mollusc associations off Lagoa dos Patos, South Brazil. Estuarine Coastal and Shelf Science, London, 32: 71-85.

Clarke, K.R. \& R.H. Green. 1988. Statistical design and analysis for a "biological effects" study. Marine Ecology Progress Series, Amelinghausen, 46: 213-226.

Costa, P.A. \& F.C Fernandes. 1993. Seasonal and spatial changes of Cephalopods caught in the Cabo Frio (Brazil upwelling ecosystem). Bulletin of Marine Science, Miami 52 (2): 751759.

DA GamA, B.A.P. \& F.C. FeRnAndes. 1994. Distribuição de crustáceos anomuros na plataforma continental de Cabo Frio (Rio de Janeiro, Brasil). Nerítica, Curitiba, 8 (1-2): 87-98.

EMILSON, I. 1961. The shelf and coastal waters off southern Brazil. Boletim do Instituto Oceanográfico, São Paulo, 11(2): 101112.

FAO. 1975. Manual of methodsin aquatic environments research. Part 1. Methods for detection, measurement and monitoring of water pollution. Fisheriesand Techical Report, Paris, 137: 1-238.

Folk, R.L. \& W.C. WARD. 1957. Brazos River bay, a study in significance of grain-size parameters. Journal of Sedimentary Petrology, Tulsa, 27: 2-26.

Franz, D. 1976. Benthic molluscan assemblages in relation to sediment gradients in Northeastern Long Island sound, Connecticut. Malacologia, Philadel phia, 15 (2): 377-399.

Gonçalves, E.M. \& P.C. Lana. 1991. Padrões de distribuição de bivalvia e gastropoda na plataforma continental da costa sudeste do Brasil (24응'S-27은'S). Nerítica, Curitiba, 6 (12): 73-92.

GraY, J.S. 1981. The ecology of marine sediments. Cambridge, Cambridge University Press, 185p.

Grillo, M.C.G.; C.R.R. Ventura \& S.H.G. Silva. 1998. Spatial distribution of bivalvia (Mollusca) in the soft-bottoms of Ilha Grande Bay, Rio de Janeiro, Brazil. Revista Brasileira de Oceanografia, São Paulo, 46 (1): 19-31.

Guille, A. 1970. Benthic bionomy of continental shelf of the French Catalane Coast. II. Benthic communities of the macrofauna. Vie et Milieu, Paris 21 (8): 149-280.

KamERMANS, P. 1992. Similarity in food source and timing of feeding in deposit- and suspension-feeding bivalves. Marine Ecology Progress Series, Amelinghausen, 104: 63-75.

LEvinTon, J.S. 1972. Stability and trophic structure in a depositfeeding and suspension-feeding communities. The American Naturalist, Chicago, 106: 472-486.

MatsUURA, Y. 1996. A probable cause of recruitment failure of the Brazilian sardine Sardinella aurita population during during the 1974/75 spawning season. South African Journal of Marine Science, Cape Town, 17: 29-35.

Merlano, J.M.D. \& M.P. Hegedus. 1994. Moluscos del caribe colombiano. Um catálogo ilustrado. Bogotá, Colciencias, Fundación Natura, Invemar, LXXIV +291p.

Netto, E.B.F. \& L.R. Gaelzer. 1991. Associações de peixes bentônicos e demersais na região de Cabo Frio, RJ, Brasil. Nerítica, Curitiba, 6(1-2): 139-156.

PIRES-VANIN, A.M.S.; J.P.S. JoRGE \& S. SARTOR. 1995. Variação diária e sazonal da fauna bêntica de plataforma continental no litoral Norte do Estado de São Paulo. Publicação Especial do Instituto Oceanográfico, São Paulo, 11: 107-114.

Rıos, E.C. 1994. Seashells of Brazil. Rio Grande, FURG, $113+492 p$.

RowE, G.T. 1985. Benthic production and processes off Baja California, northwest Africa and Peru: a classification of benthic subsystems in upwelling ecosystems. Instituto de Investigación Pesquera, Barcelona, 2: 589-612.

Schluter, D. \& R.E. Ricklefs. 1993. Species diversity. An introduction to the problem. P. 1-10. In: Schluter, D. \& Ricklefs, R.E. (eds). Species diversity in ecological communities. Chicago, The University of Chicago Press, 414p.

Suguio, K. 1973. Introdução a sedimentologia. São Paulo, Edgard Blücher, EDUSP, 317p.

Tarazona, J. \& W. Arntz. 2001. The peruvian coastal upwelling system, p. 229-244. In: U. Seeliger \& B. KJerfve (Eds). Coastal marine ecosystem of Latin America. Berlin, Springer, 311p.

VALENTIN, J.L. 2001. The Cabo Frio upwelling system, Brazil, p. 97-105. In: U. Seeliger \& B. KJerfve (Eds). Coastal marine ecosystem of Latin America. Berlin, Springer, 311p.

Ventura, C.R.R. \& F.C. Fernandes. 1995. Bathymetric distribution and population sizestructure of paxillosid seastars (Echinodermata) in the Cabo Frio upwelling ecosystem of Brazil. Bulletin of Marine Science, Miami, 56 (1): 268-282.

Ventura, C.R.R.; Falcão, A. P. C.; Santos, J. S. \& Fiori, C. S. 1997. Reproductive cycle and feeding in the starfish Astropecten brasiliensis in the Cabo Frio upwelling ecosystem (Brazil). Invertebrate Reproduction and Development, Rehovot, 31(1-3): 135-141.

Received in 13.V.2004; accepted in 10.I.2005.

Revista Brasileira de Zoologia 22 (1): 73-80, março 2005 